\title{
The Impact of Corporate Governance on Dividend Decisions: Evidence from Non-Financial Sector of Pakistan
}

\author{
Dr. IHTESHAM KHAN \\ Assistant Professor, Institute of Business Studies and Leadership \\ Abdul Wali Khan University, Mardan. \\ Email: ihtishamkhan@awkum.edu.pk
}

MUHAMMAD SHAHID

MBA, Scholar, Institute of Business Studies and Leadership

Abdul Wali Khan University, Mardan.

Email: smandoori@gmail.com

\section{Dr. SHAH RAZA KHAN}

National Bank of Pakistan.

Email:shah.raza@nbp.com.pk

\begin{abstract}
This study sought to ascertain the impact of corporate governance on dividend decisions of non-financial firms listed on Pakistan stock exchange (PSX). Panel data was collected from 2011 to 2016. Data was collected from Non financial firms annual reports and State Bank of Pakistan (SBP) data base. The STATA software was used to analyze the data. The study investigates the association of firm's performance and corporate governance. Specifically, this study investigate dividend decision (dividend per share(DPS)), corporate governance (board independence ,board size, size of firm, leverage, profitability, Insider ownership, individual ownership, and institutional ownership). A total of 42 non-financial firms are used to determine this relationship. The results show a positive significant relation between the Profitability, individual ownership with DPS. This study also found a negative and significant relationship between insiders ownership, financial institution ownership with DPS. It has also been found that Board independence, board size, firm size and leverage have negative and insignificant relationship with dividend per share (DPS).
\end{abstract}

Keywords: Corporate Governance, Dividend Decisions, Dividend Policy.

\section{Introduction}

Since early 1990s, capital market of Pakistan faced many important and critical issues, the development of a weak regulatory framework, the inefficient and non-performing stock market and stagnation, and the poorly organized and publicly owned mutual fund industry, which contributed little in the development of capital markets. From the past few year owing to tight CG rules and regulation there is a huge boom in the market capitalization along with the stock market index.

According to Bajwa et al. (2011), Pakistan is a progressing economy in Asia with inadequate rules and regulation on the arrangement of the board. There is noteworthy research potential on the effect of the synthesis of the Board of Directors (BOD) on the payments of corporate dividends (CD) in Pakistan.CG comprises of different supervisory bodies, for example, Management, Shareholders, the Board of Directors 
and auditors of the Company who secure investors' rights and have critical effect on the payment of CD (Kowalewski et al., 2007; Bebczuk, 2005).

Berkley \& Myers (2005) argue that the decision to allocate dividends is one of the biggest unsettled issues in corporate finance. However, it becomes significant in the case of CG. Dittmar et al. (2003) elaborate that the agency's dilemma was more weak point of the CGS. In a weak CG system, agency problem arises where interior shareholders obtain individual advantages from exterior shareholder. For such reason, external shareholder prefers to pay dividends (Jensen, 1986; Mayers \& Framk, 2004). Petschnigg (2005) explains the organizational framework as the organizational entities that explain and develop the financial regulations for organizations to follow.

The dividend payment provides information regarding company financial position (Afza \& Mirza, 2011). Financial researchers are granted and viewed that there is no solitary factor that affecting the CDP. The difficulties in dividend policy become more complicated due to the determinants of dividend policy. Dividend policy serves as a control instrument in minimizing conflict for shareholders and managers because shareholder wish to make profit in the form of dividend on the other hand managers want to keep the fixed assets safe by not declaring dividend.

According to Jansen (1986) and Rozeff (1982) companies employ dividend to minimize the agency's problems. In addition to dividend payments, the corporate governance the agency cost can be reduced. Gulger and Yurtuglo (2002) report the association between CG and divided of companies. In their research ownership structure and attentiveness of owners are taken as proxy for CG. The results show a negative influence of CG variables with dividend payout ratio of the firms.

Varma (1997) and Bollard (2003) discussed the board impact and its ownership on financial performance and its consequences as "recent events, such as the Enron scandal and other CG failures, have put corporate governance on the front pages of main newspapers. It has highlighted the important role that corporate governance plays in a modern economy and the consequences of getting it wrong, and it has strengthened the incentives for directors and policymakers alike to reassess the structures needed to produce high quality corporate governance."

The clear split between the two periods is critical to pushing the dividend debate in corporate finance. Amidu (2007) confirm this assertion when it revealed that the policy of dividend distribution and dividends policy have effect on company achievement oppositely. This study was also supported by Baker and Powell (2000) viewed that the allocation of dividend differs from company to company. The researchers found the nature and association between dividend payout and profitability differs between services and manufacturing industries in USA. This study was also supported by Baker and Powell (2000) that distribution of dividend varies from company to company. Who found the nature of the relationship between dividend payout and profitability vary between services and manufacturing industries in the United States.

The arrangement of the board is directed predominantly by the corporate governance system (CGS). After large scandals such as Enron, WorldCom in United States and Crescent Investment Bank in Pakistan magnetized the concentration of people to great extent towards corporate governance (CG) (Shah \& Khan, 2009). All such scandals on examination predominantly ensure one main factor that the board of directors can play a vital role in influencing the financial performance of the firms.(Bajwa, Bashir, \& Lions, 2011). These scandals have elevated the demand for investigation on the impact of the Board's attributes on corporate dividend policy (CDP) and to evade issues in the future for a few reasons. The incident of such big scandals has badly ruinous the investor confidence in corporate governance system. 


\section{Problem Statement}

For a good financial reporting system CG important determinants in corporate governance, as reported by previous researcher improve firm performance. However, it is also been reported that the existence of rules do not matter until these are implemented. Now if the rules are not implemented and firms do not performs thus they are no more likely to distribute dividend. On the other hand, if firm perform well under a strict corporate governance system firms are more likely to distribute dividend. This strand of literature is limited and thus needs investigation. Therefore, the proposed study investigates the association of firm's performance and corporate governance. Specifically this study investigate dividend decision (dividend per share), corporate governance (board independence ,board size, size of firm, leverage, profitability, Insider ownership, individual ownership, and institutional ownership).

\section{Objectives of the Study}

The main aim of this paper was to determine the influence of corporate governance on dividend decisions in non-financial firms in Pakistan. Afza and Sehrish (2011) argue on the impact of board directors decisions on dividend policy. Their study adds a new dimension to it by adding new variables of board size, board independence, insider ownership, institutional ownership, individual ownership, firm size, leverage, profitability to measure the governance system of board.

This study will be more specific from the non-financial firm's point of view.

\section{Research Questions}

The impact of Corporate Governance on dividend decisions of non-financial firms operating in Pakistan.

\section{Literature Review}

In corporate finance sector, dividend policy play important role, to solve this problem of industrials sector many studies carried out form past till now. Through agency theory the conflict between the investor and the management of the organization can be minimize releasing the dividend to the shareholder, so that the executives will not impound the retained earnings of corporations (Mayers,2000; Jenson, 1986). Rozeff (1982) were of the view that reduction in dividend is due to the presence of inside shareholder. For the sample of 1000 US organization he used DPS as a tool of measuring dividend policy and investigate very negative relationship between dividend and payout ratio and existence of inside shareholder.

According to Belden et al. (2005) argue that dividend payment raise at the presence of outside investor in the board. They investigated 524 prime American corporations for sampling and search out a negative relationship between the dividend payout and the outsider directors in the board. Mitton and Todd (2004) investigate the relationship of dividend payout ratio and corporate governance of the firm. The sample of 19 emerging economies is used and found that when there is strong corporate governance then there is positive impact on the dividend payment of the firm.

Amidu (2007) argue that various theories of corporate dividend decisions such as agency theory, customer impact, theory of signaling, life cycle theory and tax preference theory have been explained to a large extent in corporate finance literature. This section reviews current empirical literature on dividends and corporate performance.

Shah et al. (2011) reports the influence of ownership structure of firms operating in Pakistan in terms of dividend policy. In their study, a positive impact was found between ownership structures on dividend payout. Moreover, Afzal and Sherish (2011) reports the significant influence of investment opportunities, firm size on dividend policy. 
In Pakistan context there is inadequate confirmation on the impact of institutional ownership on the dividend distribution of scheduled firms; thus, these studies investigate the function of various institutional shareholder in shaping dividend profits of Pakistani firms. Pakistan is a lawful country where corporate practice is administrate by the Companies Act of 1984 and the security and Exchange Act of 1969. Unluckily the level of CG in Pakistani Firms is compared with developed countries are weak. Pakistani firms are usually in "cross circular ownership" or it is in the form of "pyramid ownership structure" the firm all affairs are carried by the principal owners.

\section{Research Methodology}

The methodology of the study is explained in the sections given below.

\section{Population of the Study}

A total of 300 non-financial firms that started their operations in Pakistan before 2011 and has not discounted till 2016 was the population of the study.

\section{Sample of the Study}

The panel data set covers a 6-year period from 2011 to 2016, with a sample of top 42 non-financial firms listed on PSX were selected based on convenience sampling techniques. The data was taken from the annual reports of companies, PSX website, and SBP official website.

\section{Variables of the Study}

Variable of the study contains dependent and independent variables with definitions and its collection source.

Table 1: Variables definitions

\begin{tabular}{|c|c|c|}
\hline Variable definition & sources & \\
\hline $\begin{array}{l}\text { Dividend per share } \\
\text { DPS }\end{array}$ & Total dividends paid / number of ordinary shares in issue & $\begin{array}{l}\text { FIRM data from } \\
\text { SBP }\end{array}$ \\
\hline $\begin{array}{l}\text { Board independence } \\
\text { BIND }\end{array}$ & $\begin{array}{l}\text { Independent non-executive directors / } \\
\text { total number of directors setting in the board }\end{array}$ & $\begin{array}{l}\text { FIRM data from } \\
\text { SBP }\end{array}$ \\
\hline $\begin{array}{l}\text { Board size } \\
\text { BSIZE }\end{array}$ & total number of directors setting in the board of directors & $\begin{array}{l}\text { FIRM data from } \\
\text { SBP }\end{array}$ \\
\hline $\begin{array}{l}\text { Size of firm } \\
\text { Size }\end{array}$ & Log of total assets & $\begin{array}{l}\text { FIRM d ata from } \\
\text { SBP }\end{array}$ \\
\hline $\begin{array}{l}\text { Leverage } \\
\text { Lev }\end{array}$ & Total debt/total assets & $\begin{array}{l}\text { FIRM da ta from } \\
\text { SBP }\end{array}$ \\
\hline $\begin{array}{l}\text { Profitability } \\
\text { PRFT }\end{array}$ & Net profit after tax/no of shares outstanding & $\begin{array}{l}\text { FIRM data from } \\
\text { SBP }\end{array}$ \\
\hline $\begin{array}{l}\text { Individual ownership } \\
\text { INVLOS }\end{array}$ & No of shares held by individual/total No of shares held & $\begin{array}{l}\text { FIRM data from } \\
\text { SBP }\end{array}$ \\
\hline $\begin{array}{l}\text { Insider ownership } \\
\text { INDROS }\end{array}$ & No of shares held by insiders/ total no of shares held & $\begin{array}{l}\text { FIRM data from } \\
\text { SBP }\end{array}$ \\
\hline $\begin{array}{l}\text { Institutional ownership } \\
\text { FINSOS }\end{array}$ & No of shares held by institutions/total no of shares held & $\begin{array}{l}\text { FIRM data from } \\
\text { SBP }\end{array}$ \\
\hline
\end{tabular}




\section{Empirical Model}

The DPS is taken as proxy for the dividend policy. The regular dividend paying companies were selected for the analysis. Model is given below.

DPSit $=\alpha_{0}+\alpha_{1} \quad$ BIND $_{\mathrm{it}}+\quad \alpha_{2}$ BSIZE $_{\mathrm{it}}+\quad \alpha_{3}$ FSIZE $_{\mathrm{it}}+\quad \alpha_{4} \mathrm{LEV}_{\mathrm{it}}+\quad \alpha_{5}$ PRFT $_{\mathrm{it}}+\quad \alpha_{6} \mathrm{INVLOS}_{\mathrm{it}}+\quad \alpha_{7} \mathrm{INDROS}_{\mathrm{it}}+$ $\alpha_{8}$ FINSOS $_{\text {it }}+\mu_{\text {it }}$

\section{Where}

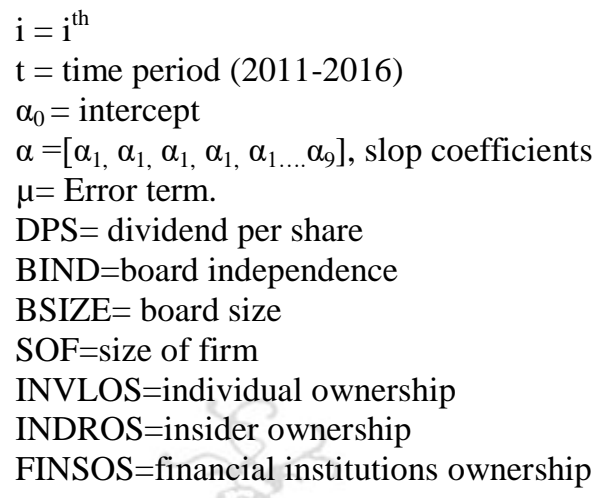

\section{Results and Data Analysis}

Descriptive statistics is given below.

Table 2: Descriptive Statistics

\begin{tabular}{|llllllll|}
\hline Variable & Obs Aean & Std. Dev. & Min & Max & Skewness & kurtosis \\
\hline DPS & 252 & 13.38226 & 31.71651 & 0 & 368.97 & 1.50 & 4.44 \\
\hline BIND & 252 & .7499562 & .1347282 & .25 & 1 & -1.127089 & 4.31 \\
\hline BSIZE & 252 & 8.400794 & 1.546774 & 7 & 14 & 1.176585 & 4.03 \\
\hline SOF & 252 & 17.08092 & 3.112615 & 8.954564 & 24.69107 & .3973118 & 3.12 \\
\hline Lev & 252 & .4509001 & .2159773 & .02 & 1.055911 & .3194175 & 2.46 \\
\hline PRFT & 252 & 20.06429 & 27.99916 & -22.6 & 207.24 & 0.164 & 4.44 \\
\hline INVLOS & 252 & .7515835 & .246935 & .0184413 & 1.615301 & -1.315337 & 4.82 \\
\hline INDROS & 252 & .1728564 & .2069363 & $3.68 \mathrm{e}-09$ & .8211273 & 1.039516 & 3.13 \\
\hline FINSOS & 252 & .8090695 & .2323935 & .0238022 & 1.092135 & -1.175715 & 3.65 \\
\hline
\end{tabular}

The Table 2 above presents descriptive statistics. A total of 252 observations were analyzed. The minimum value for DPS was 0 while the maximum was 368.97. Mean and std. Dev was 13.3822 and 31.716 respectively while the skewness and kurtosis was 1.5 and 4.44 respectively. Moreover, the BIND no of observations was 252 while the min and max values were 0.25 and 1 respectively. In the same way the BIND mean and std dev were 0.7499 and 0.134 respectively. While the skewness and kurtoses are also within the specified range. BSIZE no of observations are 252 while the min and max values are 7 and 14 respectively. Moreover, the mean and std dev is 8.4 and 1.5 respectively. The kurtosis and skewness for DSIZE is within the prescribed limits. Furthermore, for SOF the no of observation continues to be the same as 252 while the min and max values are 8.95 and 24.69 respectively. The mean and std dev are 17.08 and 3.11 respectively. The skewness and kurtosis are within the limits of statistics. The min and max value for LEV is 0.02 and 1.0559 respectively while the mean and stsd dev are 0.4509 and 0.2159 respectively. The 
min and max values for INVLOS are 0.01844 and 1.615 respectively while the mean and std dev are 0.751 and 0.246 respectively while the skewness and kurtosis are -1.315 and 4.82 respectively. The min and max values for INDROS are 0.001 and 0.821 respectively while the mean and std dev are 0.172 and 0.2069 respectively. The min and max values for FINSOS are 0.0238 and 1.0921 respectively while the mean and std dev is 0.809 and 0.232 respectively. The skewness and kurtosis are -1.175 and 3.65.

Table 3.Correlation matrix for firms

\begin{tabular}{|c|c|c|c|c|c|c|c|c|c|}
\hline Variables & DPS & BIND & BSIZE & SOF & LEV & PRFT & INVLOS & INDROS & FINSOS \\
\hline DPS & 1.0000 & & & & & & & & \\
\hline BIND & 0.2522 & 1.0000 & & & & & & & \\
\hline BSIZE & 0.0258 & 0.2168 & 1 & & & & & & \\
\hline SOF & $\begin{array}{c}- \\
0.1390\end{array}$ & $\begin{array}{c}- \\
0.0156\end{array}$ & $\begin{array}{c}- \\
0.0979\end{array}$ & 1 & & & & & \\
\hline LEV & $\begin{array}{c}- \\
0.0634\end{array}$ & $\begin{array}{c}- \\
0.0742\end{array}$ & $\begin{array}{c}- \\
0.0496\end{array}$ & 0.1288 & 1 & & & & \\
\hline PRFT & 0.7682 & $\begin{array}{c}- \\
0.1498\end{array}$ & 0.1225 & $\begin{array}{c}- \\
0.1413\end{array}$ & 0.0991 & 1 & & & \\
\hline INVLOS & 0.1113 & $\begin{array}{c}- \\
0.1016\end{array}$ & 0.0645 & 0.0064 & 0.1210 & 0.0853 & 1 & & \\
\hline INDROS & 0.1069 & $\begin{array}{c}- \\
0.2143\end{array}$ & $\begin{array}{c}- \\
0.2786\end{array}$ & 0.3298 & $\stackrel{-}{-} 0.0136$ & $\begin{array}{c}- \\
0.1491\end{array}$ & -0.1578 & 1 & \\
\hline FINSOS & 0.0242 & 0.1734 & 0.2247 & $0 . \overline{2567}$ & 0.0509 & 0.0710 & 0.1582 & -0.322 & 1 \\
\hline
\end{tabular}

The table 3 above shows the correlation among the variables. The highest correlation value between two independent variables is 0.3298 which lower then 0.80 . It means we didn't have any multicollinearity problem as suggested by Gujarati (2003).

\section{Multicollinearity Test}

Table 4. Multicollinearity

\begin{tabular}{|lll|}
\hline Variables & VIF & $1 /$ VIF \\
\hline INDROS & 4.41 & 0.226636 \\
FINSOS & 4.01 & 0.249598 \\
SOF & 1.17 & 0.855634 \\
BIND & 1.15 & 0.866227 \\
BSIZE & 1.14 & 0.878717 \\
PRFT & 1.11 & 0.897323 \\
INVLOS & 1.07 & 0.936621 \\
LEV & 1.06 & 0.944686 \\
\hline
\end{tabular}

Table 4 above shows the VIF values for the variables in our model. The highest VIF value is 4.41 . According to O'Brien (2007) in order to get rid of the multicollinearity problem all the VIF values must be within $0.05<\mathrm{VIF}<5$. So we can conclude that in our model we fulfill the minimum criteria.

\section{Fixed effect model}

The Table 5 below shows the fixed effect regression model. The DPS being the dependent variable is regressed with the independent variables like BSIZE, SOF,BIND,LEV, PRFT, INVLOS, INDROS, and FINSOS of non-financial firms to find its impact using Fixed Effect Panel Least Square Method. The Rsquare value is $30.53 \%$. BIND has a positive relation with DPS but it is also statistically insignificant this 
study also supported by Belden et al. (2000) he also found the same result of the study. BSIZE has a positive relation with DPS. While Klein (2002) reports that board size has an impact on control mechanism. In our analysis, it is statistically insignificant but at level 5\%.SOF has also a negative relation with DPS and it is statistically insignificant at level 5\%. Richard (2001) also supports our result of the study and he also found the negative and insignificant result of the study.

Table 5. Fixed Effect Panel Least Square

\begin{tabular}{|c|c|c|c|c|}
\hline Variables & Coefficients & St. errors & T-Values & P $>|\mathrm{t}|$ \\
\hline BIND & 15.99321 & 14.75385 & 1.08 & 0.28 \\
\hline BSIZE & 1.935218 & 2.074275 & 0.93 & 0.352 \\
\hline SOF & -0.4422468 & 1.698212 & -0.26 & 0.795 \\
\hline LEV & -8.30161 & 8.810712 & -0.94 & 0.347 \\
\hline PRFT & 0.6604713 & 0.093825 & 7.04 & 0 \\
\hline INVLOS & 7.982306 & 5.591207 & 2.43 & 0.055 \\
\hline INDROS & -36.15407 & 19.45046 & -1.86 & 0.065 \\
\hline FINSOS & -35.30606 & 9.637593 & -3.66 & 0 \\
\hline cons & 11.99112 & 36.3823 & 0.33 & 0.742 \\
\hline R-sq & 0.3053 & & & \\
\hline
\end{tabular}

Hafeez and Attiya Ahmad (2010) found negative and insignificant result of the LEV in their study on the other hand baker et al. (2007) and Belans et al. (2007) also found the same results these study support our result of leverage. While PRFT and INVLOS have a positive relation with DPS and both are statistically significant and the result of Eriostis and Vasilios (2003) and Alam and Hossain (2012) also support our result. INDROS has negative relation with DPS but it is significant at level $10 \%$ and this study also support by Al Malkwai (2007). FINSOS has a negative relation with DPS and it is statistically significant at level $1 \%$ this study supported by Afzal and Sehrish (2010).

\section{Random Effect Method}

Table 6. Random Effect Panel Least Square

\begin{tabular}{|c|c|c|c|c|}
\hline Variables & Coefficients & St. errors & Z-Values & $\mathrm{P}>|\mathrm{z}|$ \\
\hline BIND & 12.50648 & 11.37733 & -1.1 & 0.272 \\
\hline BSIZE & 0.4125166 & 1.196393 & -0.34 & 0.73 \\
\hline SOF & -0.2939284 & 0.64824 & -0.45 & 0.65 \\
\hline LEV & -4.092844 & 6.991013 & -0.59 & 0.558 \\
\hline PRFT & 0.8001386 & 0.060135 & 13.31 & 0.00 \\
\hline INVLOS & 7.514979 & 5.182022 & 1.45 & 0.08 \\
\hline INDROS & -37.46226 & 13.13525 & -2.85 & 0.004 \\
\hline FINSOS & -37.85676 & 9.364876 & -4.04 & 0.00 \\
\hline cons & 48.49507 & 19.66706 & 2.47 & 0.014 \\
\hline R-sq & 0.2845 & & & \\
\hline
\end{tabular}

The Table 6 shows dependent variable DPS that is being regressed by the independent variables like BSIZE, SOF,BIND,LEV, PRFT, INVLOS, INDROS, and FINSOS of non-financial firms to find its impact using Fixed Effect Panel Least Square Method. The R-square value is 30.53\%. BIND has a positive relation with DPS but it is also statistically insignificant this study also supported by Belden et al. (2000) he also found the same result of the study. BSIZE has a positive relation with DPS. While Klein (2002) reports that large boards have an influence on the control of the firm. SOF has also a negative relation with DPS and it is statistically insignificant at level 5\%. Richard (2001) also supports our result of the study and he also found the negative and insignificant result of the study. They found negative and insignificant result of the LEV in their study on the other hand baker et al. (2007). Belans et al., (2007) also found the same 
results these study support our result of leverage. While PRFT and INVLOS have a positive relation with DPS and both are statistically significant and the result of Eriostis and vasilios (2003) also support our result. INDROS has negative relation with DPS but it is significant at level 10\% and this study also support by Al Malkwai (2007). FINSOS has a negative relation with DPS and it is statistically significant at level $1 \%$ this study supported by Afzal and Sehrish (2010).

\section{Hausman test}

Table 7: Hausman test

\begin{tabular}{|c|c|c|c|c|}
\hline Variables & Random & Fixed & Difference & S.E \\
\hline BIND & -12.50648 & 15.99321 & -28.49969 & . \\
\hline BSIZE & $\overline{0} .4125166$ & 1.935218 & -2.347735 & . \\
\hline SOF & $\overline{0} \mathbf{-} 2939284$ & $\overline{0}-4422468$ & 0.1483184 & . \\
\hline LEV & -4.092844 & -8.30161 & 4.208766 & . \\
\hline PRFT/EPS & 0.8001386 & 0.6604713 & 0.1396673 & . \\
\hline INVLOS & 7.514979 & 7.982306 & $\overline{0} .4673273$ & . \\
\hline INDROS & -37.46226 & -36.15407 & -1.308192 & . \\
\hline FINSOS & -37.85676 & -35.30606 & -2.550705 & . \\
\hline
\end{tabular}

In order to select between the suitable models for our analysis Hausman test should applied (Asteriou \& Hall, 2007). As per the Null hypothesis: Fixed effect model is better while the alternate hypothesis: Random effect model. As the P-value is 0.008 so, fixed effect is the suitable model of analysis for our model.

\section{Conclusion}

The main focus for the introduction of the corporate governance was to protect the investor's right. The focus on paying dividend in Pakistani firms is very low. Which shows that the firm authorizes didn't give due importance to the shareholders. Now, to give due importance to the shareholder or the real owners of the firms, corporate governance practices were introduced by SECP in Pakistan. In this regard the main for this paper was to investigate the influence of the corporate governance practices on dividend polices in Pakistani non financial firms listed on PSX. The sample period selected for the research was from 2011 to 2016. A total of 42 firms were selected based on convince sampling. The results show that firms with large boards that represent directors both from minority shareholder and large shareholders has a high dividend payout ratio. Moreover, the board independence didn't show any influence on DPS. An important result was indorsed in this paper was that large individual ownership shows little concern towards dividend payments. Mostly the insider owners has the influence on the decision of whether to pay dividend or not. A significant relation was observed between the institutional ownership and DPS but the relation was negative in nature. Higher the level of institutional ownership lower will the DPS and vice versa. In Pakistan, mostly the dividend is paid regularly but the magnitude of the dividend is low. Moreover, if the firms are high leverage this magnitude of dividend paying ratio is further effected (Baker et al., 2007).

So, we may conclude based on our findings that large board size has an influence on the dividend policy of the firm. It may improve the ratio DPS in a positive way with the concern that the executive and nonexecutive directors ratio should be kept in check. Moreover, individual ownership, insider ownership and institutional ownership has significant role to play in the dividend decision making but the individual 
ownership shows a positive influence while the insider ownership and institutional ownership has negative influence on the dividend decision's making. The SECP can play a positive role in introducing and making it compulsory for the non-financial firms to adopt the corporate governance practices to safe guard the interest of the shareholders.

\section{Limitation of the Study}

During the data collection process of this research, it has been observed that hardly 30 percent of the sample companies fulfill my requirements of the research as we randomly select the companies for data collection. Mostly the annual reports of companies were not available and were not updated till 2016 regarding the corporate governance compliance code. we collect data from the annual reports of many firms, they paid high amount of dividend per share while they had earn less than that.

\section{References}

Abdelsalam, O., El-Masry, A. and Elsegini, S. (2008), "Board Composition, Ownership Structure and Dividend Policies in an Emerging Market: Further Evidence from CASE 50”, Managerial Finance, Vol. 34, No. 12, pp. 953-964.

Adu-Boanyah, E., Ayentimi, T. D., and Osei-Yaw, F. (2013), "Determinants of dividend payout policy of some selected manufacturing firms listed on the Ghana Stock Exchange", Research Journal of Finance and Accounting, Vol. 4(5), pp. 49-60.

Afza, T. and Mirza, H. H. (2010), "Ownership Structure and Cash Flows as Determinants of Corporate Dividend Policy in Pakistan”, International Business Research, Vol. 3, No. 3, pp. 210-221.

Afzal M, Sehrish S (2011). Ownership Structure, Board Composition and Dividend Policy in Pakistan. Agency Costs?" Business and Society Review, Vol. 110, No. 2, pp. 171-180.

Afzal, M. U. H. A. M. M. A. D., \&Sehrish, S. A. B. A. (2011). Ownership structure, board composition and dividend policy in Pakistan. African Journal of Business Management, 7(11), 811-817.

Agyei, S.K. and Marfo-Yiadom, E. (2011a), "Dividend Policy and Bank Performance in Ghana", International Journal of Economics and Finance, Vol. 3(4), pp. 202-207.

Ahmed, H. and Javid, A. (2009), "Dynamics and Determinants of Dividend Policy in Pakistan (Evidence from Karachi Stock Exchange Non-financial Listed Firms)", International Research Journal of Finance and Economics, Issue 25, pp. 148-171.

Ahmed, H. and Javid, A. (2009), "The Determinants of Dividend Policy in Pakistan", International Research Journal of Finance and Economics, Issue 29, pp. 110-125.

Ahmed, H. and Javid, A. (2010), "The Ownership Structure and Dividend Payout Policy in Pakistan (Evidence from Karachi Stock Exchange 100 Index)”, International Journal of Business Management and Economic Research, Vol. 1, No. 1, pp. 58-69.

Aivazian, V., Booth, L. \& Cleary, S. (2003) "Do Emerging Market Firms Follow Different Dividend Policies from U.S. Firms?” The Journal of Financial Research, Vol. 26: 371-87.

Al-Kuwari, D. (2009) "Determinants of the Dividend Policy in Emerging Stock Exchanges:The Case of GCC Countries" Global Economy \& Finance Journal, Vol. 2(2): 38-63.

Allen, F. \& Michaely, R. (2003) "Payout Policy, Handbook of the Economics of Finance, in: G.M. Constantinides\& M. Harris \& R. M. Stulz (ed.)" Handbook of the Economics of Finance, edition 1: chapter 7: 337-429.

Al-Malkawi, H. N. (2007) "Determinants of Corporate Dividend Policy in Jordan: An Application of the Tobit Model” Journal of Economic and Administrative Sciences, Vol. 23(2): 44-70.

Al-Twaijry, A. A. (2007), "Dividend Policy and Payout Ratio: Evidence from the Kuala Lumpur Stock Exchange", Journal of Risk Finance, Vol. 8(4), pp. 349-363

Amidu, M. \& Abor, J. (2006) "Determinants of Dividend Payout Ratios in Ghana" The Journal of Risk Finance, Vol.7 (2): 136-45.

Amidu, M. (2007), "How Does Dividend Policy Affect Performance of the Firm on Ghana Stock Exchange?",Investment Management and Financial Innovations, Vol. 4, Issue 2, 103-112. 
Amidu, M. and Abor, J. (2006), "Determinants of the Dividend Payout Ratio in Ghana", The Journal of Risk Finance, Vol. 7(2), pp. 136-145.

Applied Economics, Vol. 35, pp. 51-61.

Arnott, R. and Asness, C. (2003), "Surprise! Higher Dividends - Higher Earnings Growth", Financial Analysts Journal, Vol. 59 No. 1, pp. 70-87.

Asteriou, D., \& Hall, S.G. (2007). Applied econometrics, (2nd ed.). Basingstoke, Hampshire : Palgrave Macmillan hound mills.

Badu, E.A. (2013), "Determinants of Dividend Payout Policy of Listed Financial Institutions in Ghana", Research Journal of Finance and Accounting, Vol.4 (7), pp. 185-190.

Bajwa AS, Bashir A, Lions C (2011). The impact of ownership and board composition on financial performance of the firm. Empirical Evidence pp.1-126.

Baker, H.K. and Powell, G.E. (2000), "Determinants of Corporate Dividend Policy: A Survey of NYSE Firms", Financial Practice and Education, Vol. 10, pp. 29-40.

Baker, J. D., Polovina, J. J., \& Howell, E. A. (2007). Effect of variable oceanic productivity on the survival of an upper trophic predator, the Hawaiian monk seal Monachusschauinslandi. Marine Ecology Progress Series, 346, 277-283.

Bali R (2003). “An Empirical Analysis of Stock Returns around Dividend Changes”, Appl. Econ. 35:51-61.

Baliga B, Moyer R, Ramesh P (1996). CEO duality and firm performance: What's the fuss? Strateg. Manage. J. 17:41-53.

Banerjee, S., Vladimir A. G. \& Paul A. S. (2007) "Stock Market Liquidity and Firm Dividend Policy" Journal of Financial and Quantitative Analysis, Vol. 42(2): 369-98.

Bebczuk RN (2005). "Corporate Governance and Ownership: Measurement and Impact on Corporate Performance and Dividend Policies in Argentina”, Research Network Working Papers, R-516, Center for Financial Stability and Universidad Nacional De La Plata.

Belden S, Fister T, Knapp B (2005). "Dividends and Directors: Do Outsiders Reduce Agency Costs?” Bus. Soc. Rev. 110(2):171-180.

Berkley R, Myers S (2005). "Principles of corporate finance. 8th ed, London: McGraw- Hill. Black F, 1976 „The Dividend Puzzle ${ }^{e e}$, J. Port. Manage. 2:5-8.

Bernstein, P. L. (1996) "Dividends: the Puzzle” Journal of Applied Corporate Finance, Vol. 9(1): 4-15.

Bhattacharya S (1979). "Imperfect Information, Dividend Policy and "the Bird in the Hand"Fallacy", Bell J. Econ. 10(1):259-270

Biers, Dan editor 1998. Crash of '97: How the Financial Crisis is Reshaping Asia. Review Publishing Company Limited (Far Eastern Economic Review), Hong Kong

Black, F. (1976) "The Dividend Puzzle” The Journal of Portfolio Management, Vol. 2: 5-8

Bollard, D. A. (2003). Corporate governance in the financial sector. Reserve Bank of New Zealand Bulletin, 66.

Brealey R. \& Myers, S. (2005) "Principles of Corporate Finance (8th edition): London: McGraw-Hill. Black F., 1976, 'The Dividend Puzzle', Journal of Portfolio Management, Vol. 2 (2): 5-8.

Caballero, Ricardo and Arvind Krishnamurthy 1998. "Emerging Markets Crises: An Asset Markets Perspective." Mimeo, November 21, MIT.

Cheema A (2003) “Corporate governance in Pakistan: issues and concerns" The Journalvol .8, No 2, NIPA Karacahi.

Chen, J. \&Dhiensiri, N. (2009) "Determinants of Dividend Policy: The Evidence from New Zealand" International Research Journal of Finance and Economics, Issue 34: 18-28.

Corporate Performance and Dividend Policies in Argentina", Research Network Working.

Corsetti, Giancarlo, Paolo Pesenti, and NourielRoubini 1998. "What caused the Asian currency and financial crisis?" Mimeo, Revised March.

Crutchley, C. \& Hansen, R. (1989) “A Test of the Agency Theory of Managerial Ownership, Corporate Leverage and Corporate Dividends" Financial Management, Vol.18: 36-46.

De Angelo H, De Angelo L, Douglas JS (2004). "Are dividends disappearing? Dividend concentration and the consolidation of earnings", J. Financ. Econ. 72:425-456. 
De Angelo, Harry, Linda DeAngelo, and Douglas J. Skinner. (2004) "Are dividends disappearing? Dividend concentration and the consolidation of earnings", Journal of Financial Economics, 72, 425456.

Directors", Journal of Financial Economics, Vol. 40, No. 2, pp. 185-211.

Dittmar, A., Mahrt-Smith, J. and Servaes, H. (2003) International corporate governance and corporate cash holdings, Journal of Financial and Quantitative Analysis, 38, 111-134.

Dividend and Compensation Policies" Journal of Financial Economics, Vol. 32(3): 263-92.

D'Souza J, Saxena AK (1999). "Agency cost, market risk, investment opportunities and dividend policy an international perspective." Manag. Finan. 25:35-44.

Easterbrook, F. H. (1984) "Two Agency-Cost Explanations of Dividends" American Economic Review, Vol.74 (4): 221-30. Economic Review, Vol. 20, pp. 24-32.

Eriotis, N. (2005) "The Effect of Distributed Earnings and Size of the Firm to Its Dividend Policy: Some Greek Data" International Business and Economics Journal, Vol. 4(1): 67-74.

Fama, E. F. \& French, K. R. (2002) "Testing Trade-Off and Pecking Order Predictions about Dividends and Debt" The Review of Financial Studies, Vol. 15: 1-33.

Glen, J., Karmokolias, Y., Miller, R. and Shah, S. (1995) "Dividend Policy and Behavior in Emerging Markets" IFC Discussion Paper No. 26, www.ifc.org

Gordon, M. J. (1963). Optimal investment and financing policy. The Journal of finance, 18(2), $264-272$.

Jensen, M. C. (1986). Agency costs of free cash flow, corporate finance, and takeovers. The American economic review, 76(2), 323-329.

Jensen, M. C. (1993). The modern industrial revolution, exit, and the failure of internal control systems. the Journal of Finance, 48(3), 831-880.

Klein, A. (2002). Audit committee, board of director characteristics, and earnings management. Journal of accounting and economics, 33(3), 375-400.

Kowalewski, O., Stetsyuk, I., \& Talavera, O. (2007). Corporate governance and dividend policy in Poland.

Levin A, Lin C-F (1992) Unit root tests in panel data: Asymptotic and finite sample propertics. Technical Report 92-93. Department of Economics, University of California at San Diego

Miller, M. H., \& Modigliani, F. (1961). Dividend policy, growth, and the valuation of shares. the Journal of Business, 34(4), 411-433.

Mitton, T. (2004). Corporate governance and dividend policy in emerging markets. Emerging Markets Review, 5(4), 409-426.

Petschnigg, R. (2005). The institutional framework for financial market policy in the USA seen from an EU perspective.

Rozeff, M. S. (1982). Growth, beta and agency costs as determinants of dividend payout ratios. Journal of financial Research, 5(3), 249-259.

SHAH, S. Z. A. (2009). Corporate governance and financial performance: A comparative study of developing and developed markets (Doctoral dissertation, Mohammad Ali Jinnah University, Islamabad).

Shah, S. Z. A., \& Hussain, Z. (2012). Impact of ownership structure on firm performance evidence from non-financial listed companies at Karachi Stock Exchange. International Research Journal of Finance and Economics, 84, 6-13.

Varma, J. R. (1997). Corporate governance in India: disciplining the dominant shareholder. IIMB Management Review, 9(4), 5-18.

WaliUllah, \&Nishat, M. (2008). Capital structure choice in an emerging market: evidence from listed firms in Pakistan. Paper presented at the 21st Australasian Finance and Banking Conference.

Yermack, D. (1996). Higher market valuation of companies with a small board of directors. Journal of financial economics, 40(2), 185-211. 